\title{
Towards the future of plastic surgery: from flaps to microsurgery and regenerative medicine and biofabrication?
}

\author{
Raymund E. Horch ${ }^{1}$, Annika Weigand ${ }^{1}$, Harald Wajant ${ }^{2}$, Ran An ${ }^{1,3}$, Jia-Min Sun ${ }^{3}$, Andreas Arkudas ${ }^{1}$ \\ ${ }^{1}$ Department of Plastic and Hand Surgery and Laboratory for Tissue Engineering and Regenerative Medicine, University Hospital Erlangen, \\ Friedrich-Alexander University Erlangen-Nuernberg FAU, 91054 Erlangen, Germany. \\ ${ }^{2}$ Division of Molecular Internal Medicine, Department of Internal Medicine II, University Hospital Würzburg, Julius-Maximilians-Universität \\ Würzburg, 97070 Würzburg, Germany. \\ ${ }^{3}$ Union Plastic and Aesthetic Hospital, Huazhong University of Science and Technology, Wuhan Union Hospital, Wuhan 430022, Hubei, China.
}

Correspondence to: Prof. Raymund E. Horch, Department of Plastic and Hand Surgery and Laboratory for Tissue Engineering and Regenerative Medicine, University Hospital Erlangen, Friedrich-Alexander University Erlangen-Nuernberg FAU, 91054 Erlangen, Germany.

E-mail: Raymund.horch@uk-erlangen.de

How to cite this article: Horch RE, Weigand A, Wajant H, An R, Sun JM, Arkudas A. Towards the future of plastic surgery: from flaps to microsurgery and regenerative medicine and biofabrication? Plast Aesthet Res 2017;4:185-9.

Plastic surgery is a specialty that is now worldwide recognized as its own academic discipline within the surgical community. The roots however are as old as $600 \mathrm{BC}$ when in the Sushruta Ayurveda the reconstruction of a nose with a flap from the forehead was described. Plastic surgery is a problem solving discipline that meanwhile is an integral part within modern surgical concepts. A number of groundbreaking inventions and developments from plastic surgery had led to relevant innovations and these influenced the whole field of surgical specialities, including the nobel prize for the first successful renal transplantation, performed by the plastic surgeon John Murray. Although principal details of operation techniques that had been described as early as $600 \mathrm{BC}$ are still part of the surgical armamentarium, many innovative methods have enriched the current spectrum of possibilities. Whereas over many centuries techniques of reconstruction utilized delayed pedicled random pattern flaps and needed multi stage procedures (even before the advent of anaesthesia) today axially vascularized and perforator based flaps have replaced these often tedious and painful techniques. It was the publication of the Indian method of nose reconstruction in the Gentlemen's magazine in England that replaced the random pattern flap based method that was described in Tagliacozzi's two volume book De Curtorum Chirurgia per Insitionem (1597), where he detailed the different surgical steps with graphic illustrations that became a hallmark of surgical textbooks ever since.

When within the last decades the rapid development of microsurgery allowed for transplantation of vascularized tissue to almost any part of the body this spread as a fascinating extension of older surgical methods to many other surgical specialities as well. Modern reconstructive and oncological concepts rely on the interdisciplinary character of plastic surgery making our specialty an essential part of any reconstructive

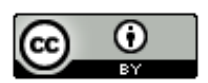

and reproduction identical terms.

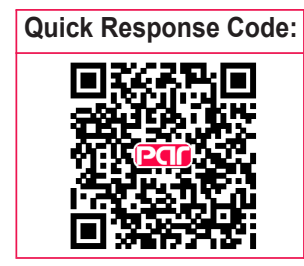


concept and rendering plastic surgery as a problem solving discipline within the concert of all medical specialities. It has been shown that such modern interdisciplinary concepts contribute significantly to improving the patient's quality of life.

As an example one can look at the salvage of hypovascularized wounds in the lower extremity, that is made possible by transferring well vascularized tissue utilizing microsurgery. This concept utilizes the surgical induction of angiogenesis for the treatment of chronic, poorly vascularized wounds, such as in diabetic ulcers and ulcers following arteriosclerotic disease $\mathrm{e}^{[1-5]}$. Autologous venous bypass grafts can be used as a prolongation or as arterio-venous loops to allow for a distal free flap connection even in the absence of appropriate local vessels, before amputation is necessitated. We have been using this concept for more than 20 years now and have investigated a larger cohort of such selected patients who needed bypasses and microsurgical free flaps. We have therefore assessed and advocated an algorithm based on our results and from current literature data ${ }^{[6-11]}$.

Perforator flaps have significantly contributed to a further reduction in donor sit morbidity when compared to myocutaneous or muscle flaps. Perforator flaps have been advocated to be another soft tissue choice for all zones of the lower extremity, recognizing that donor site function preservation is their major asset because in such perforator flaps no muscle needs to be included [Figures 1 and 2]. When patients do not have relevant microperfusion problems in the recipient area and when arterial inflow is not compromised, peninsular, propellor, or advancement perforator flaps can be regarded as valuable local non-microsurgical flap alternatives in appropriate cases ${ }^{[12]}$. However, the indication to decide whether a local flap or a free tissue transfer is necessary depends on the localization

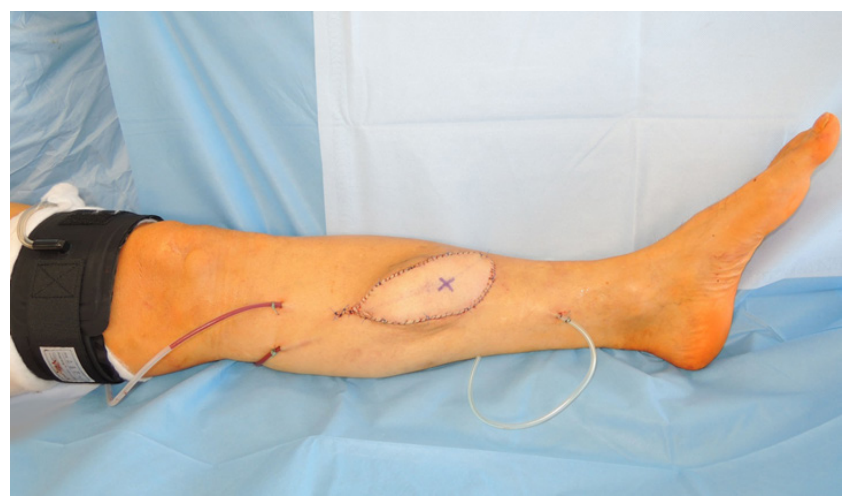

Figure 1: A 58-year-old male patient with pretibial defect following radical resection of malignant melanoma with exposed tibial bone and immediate aspect at the end of free microvascular anterolateral thigh flap transfer and the size of the defect as well as on the vascular situation of the recipient site ${ }^{[13]}$. In diabetic foot ulcers for instance the indications for local flaps are rather limited. It also has to be taken into account that any local flap does not only cause a donor site defect but also may further deteriorate the vascular supply of the distal extremity. In experimental studies the potential role of neo-angiogenesis at the non-ischemic/ ischemic interfaces are key to the biological healing process. Such interfaces occur after transfer of free vascularized flaps into ischemic wounds ${ }^{[14,15]}$. Due to the standardization of microsurgery the age of patients seems to be no hindrance to become eligible for free flap transfers to the lower extremity. A correlation between flap loss and increased risk factors and age was not found in the elderly population so far ${ }^{[16-18]}$.

We have gained experience with more than 100 patients who received a bypass or an av-loop (primarily or staged) along with a free flap and we could show that weighed against the gain in quality of life the donor site morbidity is comparatively low and acceptable. Nevertheless a consequent patient selection and a thorough planning can help to keep the rate of complications low.

It is the daily routine of plastic surgeons to deal with

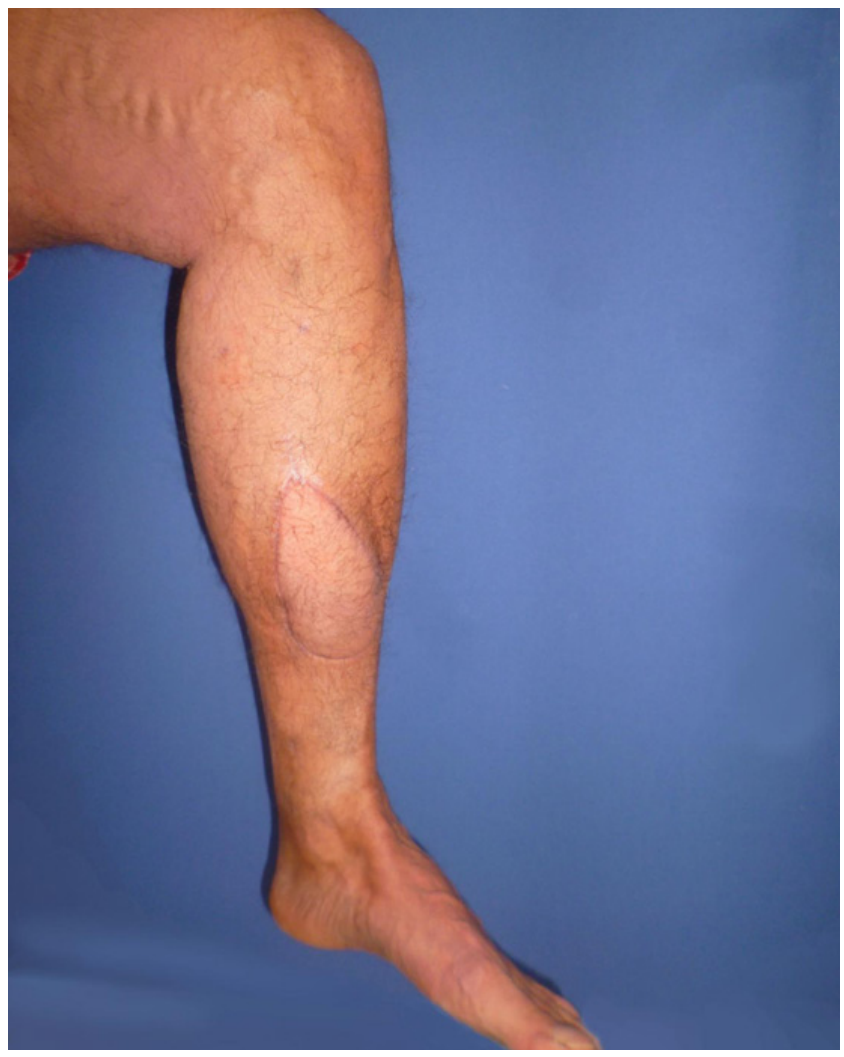

Figure 2: Three months postoperative aspect of defect reconstruction with free microvascular anterolateral thigh fasciocutaneous flap transfer to pretibial defect 


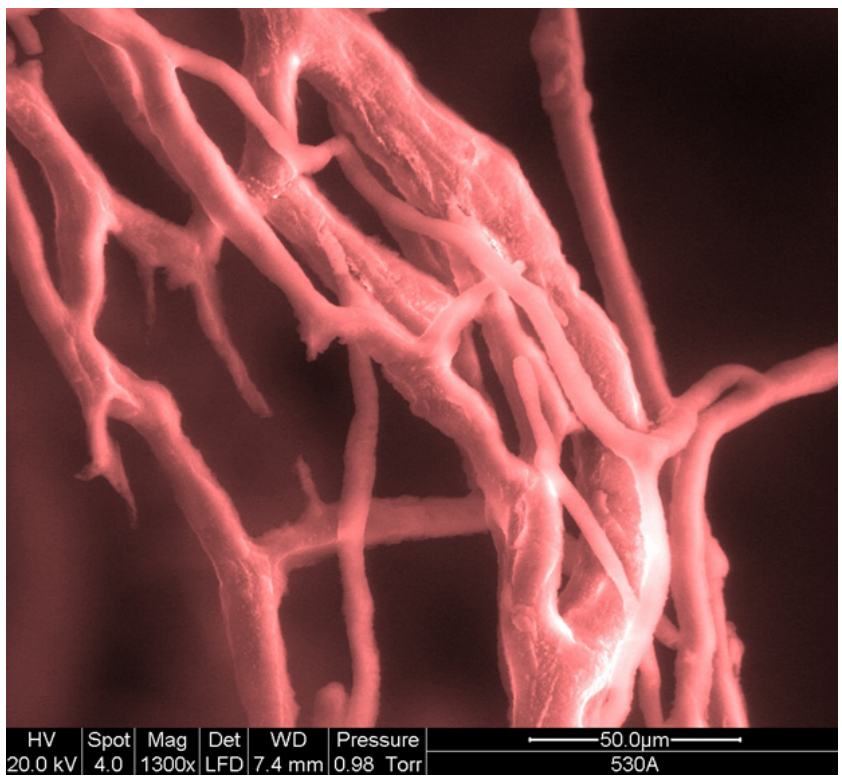

Figure 3: 3D negative imprint of angio- and vasculogenesis network sprouting out from arterio-venous loop in an isolated chamber after 6 weeks

tissue loss and tissue replacement. Therefore it is of no wonder that plastic surgeons who were engaged in replacing lost tissue were amongst the initial founders of what has then be termed tissue engineering (TE) and hence have been involved into all kinds of research in TE and regenerative medicine. Basically the initial idea of TE was to build appropriate scaffolds and then seed cells on such matrices to transplant them into the recipient area. In the laboratory considerable results have been obtained in generating replacement tissue but have not found their way into daily clinical practice yet. The main obstacle has turned out to be the lack of initial vascularization especially in large constructs ${ }^{[19]}$. These suffer from sufficient initial blood supply after transplantation to nourish inherent or adherent cells right from the beginning of their inset. One possible way to overcome this problem is the prevascularization of such scaffolds utilizing microsurgically created arterio-venous (av-) loops to three-dimensionally vascularize large constructs before the designated cells are inoculated [Figure 3]. These prevascularized constructs can then be successfully transplanted ${ }^{[20-23]}$. Methods derived from such approaches have been successfully implemented into the clinical scenario ${ }^{[24-27]}$. For the first time in the literature we were able to successfully apply av-loops in two patients, fill in the patient's own bone marrow stem cells, along with a hydroxyl-apatite powder and fibrin sealant and we then have seen a permanent replacement and restoration of large human bone defects ${ }^{[28]}$. This is a very promising approach that offers a way from bench to bedside already in selected cases. Latest advances now include the integration of 3D bioprinting of cells

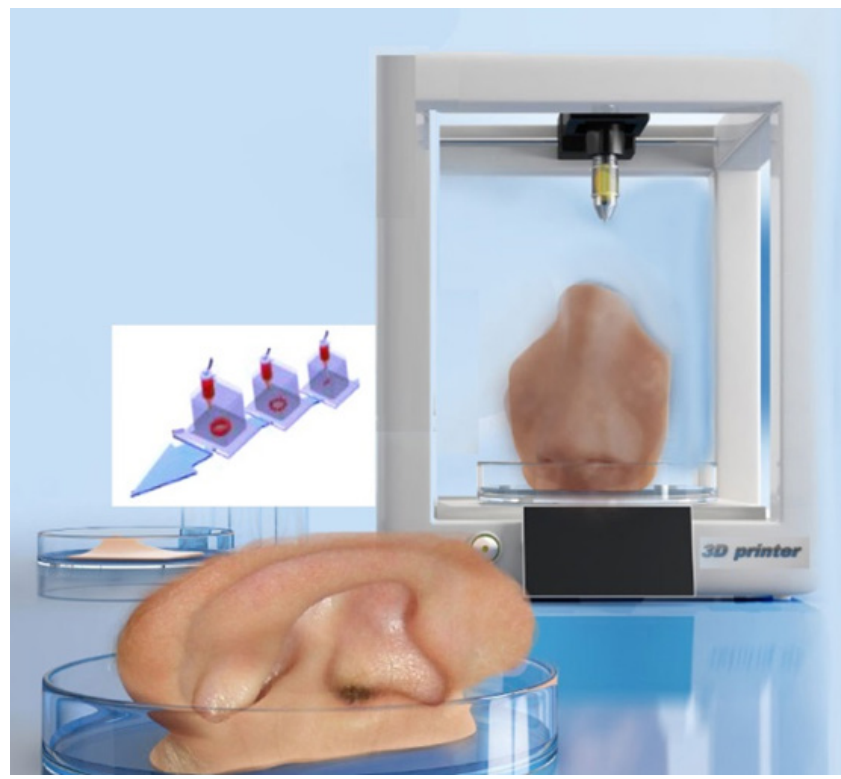

Figure 4: Future applications of 3D bioprinting envision a precise specialdeposition of cells and molecules into 3D scaffolds to mimick natural tissue conditions and to facilitate artificial tissue replacement, such as in this artistic rendering an ear or a noise for example, using tools of biofabrication

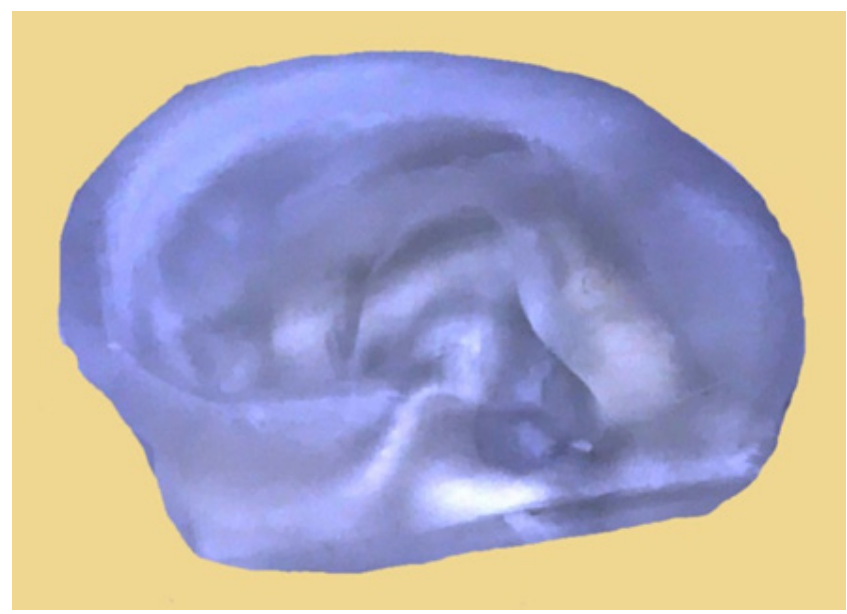

Figure 5: 3D bioprinted ear frame work with bioink that can contain living cells to be positioned into the printed construct

and proteins together with biodegradable matrices [Figures 4 and 5], generally now perceived as the new field of "biofabrication"[29]. It has been postulated by researchers that bioprinting would now be on the cusp of entering the translational phase where laboratory research practices can be scaled up into manufacturing products specifically designed for individual patients ${ }^{[30]}$. In addition to tissue replacement such modalities could help to also fight systemic conditions, such as diabetes mellitus or malignant diseases. With the help of biofabricated protein synthesizing producer cells in a $3 \mathrm{D}$ microvascularly connected defined container it can become possible to treat systemic or local diseaeses. The advantage of such containers with $3 D$ 
hierarchically printed reporter/producer cells would be that it could potentially produce antibodies in a clinically relevant amount and could be removed when no longer needed. Ravnic et al. ${ }^{[31]}$ reported on recent successful attempts to generate beta-cells and how this can be coupled with bioprinting technologies in order to fabricate pancreas tissues, which holds great potential for type 1 diabetes. They postulated that it would be possible to integrate vascularization and encapsulation in bioprinted tissues. This would lend other future prospects, such as pancreas-on-a-chip or organoids on a chip ${ }^{[31]}$. Our own group is actively investigating the value of bioprinting to generate such arterialized $3 \mathrm{D}$ prevascularized containers which can then be loaded with protein producing cells. These cells are supposed to continuously express functional substances and address specific functions in the recipient organism. This interdisciplinary approach is a fine example of how we can combine the knowledge, skills and expertise of plastic surgical microvascular techniques with the science of bioengineering and biology. Therefore, it seems promising to help our patients better than today with customized solutions to overcome morbidities that are rarely curable today. In summary, all the findings from regenerative medicine and tissue engineering are now more and more merging into the new field of biofabrication. This might well enrich our daily clinical practice of to the benefit of our patients by combining the art of plastic surgery with basic science ${ }^{[32,33]}$.

\section{DECLARATIONS}

\section{Authors' contributions}

Designed and wrote the manuscript, performed literature research, produced the figures and finalized the manuscript: R. E. Horch

Discussed the content, read and corrected and proofread the final manuscript: A. Weigand, H. Wajant, R. An, J.M. Sun, A. Arkudas

\section{Financial support and sponsorship}

None.

\section{Conflicts of interest}

There are no conflicts of interest.

\section{Patient consent}

Not applicable.

\section{Ethics approval}

Not applicable.

\section{REFERENCES}

1. Biemer E, Jaeger K. Drug treatment, after care and secondary interventions following lower leg reconstruction by free tissue transfer. Chirurg 1986;57:140. (in German)

2. Hay EL, Shealy GJ, Hanel DP, Stoddard LC. Lower extremity salvage with microvascular free flaps. J S C Med Assoc 1985;81:311-6.

3. Hallock GG. Severe lower-extremity injury. The rationale for microsurgical reconstruction. Orthop Rev 1986;15:465-70.

4. Walgenbach KJ, Voigt M, Andree C, Stark GB, Horch RE. Management of hypovascularized wounds not responding to conventional therapy by means of free muscle transplantation. Vasa 2001;30:206-11

5. Ducic I, Rao SS, Attinger CE. Outcomes of microvascular reconstruction of single-vessel lower extremities: limb salvage versus amputation. J Reconstr Microsurg 2009;25:475-8.

6. Daigeler A, Kneser U, Fansa H, Riester T, Uder M, Horch RE; Deutschsprachige Gemeinschaft für Mikrochirurgie der peripheren Nerven und Gefäße. Reconstruction of the vascular compromised lower extremity - report of the consensus workshop at the 35. Meeting of the DAM (Deutschsprachige Gemeinschaft fur Mikrochirurgie der peripheren Nerven und Gefasse) 2013 in Deidesheim. Handchir Mikrochir Plast Chir 2014;46:248-55. (in German)

7. Kneser U, Arkudas A, Beier JP, Dragu A, Stübinger A, Lang W, Horch RE. Extended skin and soft tissue defects after vascular wounds: plastic surgical concepts. Zentralbl Chir 2013;138:536-42. (in German)

8. Horch RE, Horbach T, Lang W. The nutrient omentum free flap: revascularization with vein bypasses and greater omentum flap in severe arterial ulcers. J Vasc Surg 2007;45:837-40.

9. Horch RE, Lang W, Arkudas A, Taeger C, Kneser U, Schmitz M, Beier JP. Nutrient free flaps with vascular bypasses for extremity salvage in patients with chronic limb ischemia. $J$ Cardiovasc Surg (Torino) 2014;55:265-72.

10. Horch RE, Lang W, Meyer A, Schmitz M. Distal pedal bypasses combined with free microsurgical flaps in chronic limb ischaemia for problematic wounds. Int Wound J 2016;13:425-6.

11. Horch RE, Walgenbach KJ, Voigt M, Stark GB. The free "emergency" rectus abdominis flap transfer for coverage of complex hand injuries. Langenbecks Arch Chir Suppl Kongressbd 1998;115:1194-6. (in German)

12. Hallock GG. A paradigm shift in flap selection protocols for zones of the lower extremity using perforator flaps. J Reconstr Microsurg 2013;29:233-40.

13. Colen LB. Limb salvage in the patient with severe peripheral vascular disease: the role of microsurgical free-tissue transfer. Plast Reconstr Surg 1987;79:389-95.

14. Walgenbach KJ, Horch R, Voigt M, Andree C, Tánczos E, Stark GB. Free microsurgical flap-plasty in reconstructive therapy of diabetic foot ulcer. Zentralbl Chir 1999;124 Suppl 1:40-4. (in German)

15. Walgenbach KJ, Voigt M, Horch R, Stark GB. Surgically-induced angiogenesis as basic principle in treatment ov hypovascularized wounds--the nutritive flap. Langenbecks Arch Chir Suppl Kongressbd 1998;115:1186-8. (in German)

16. Goldberg JA, Alpert BS, Lineaweaver WC, Buncke HJ. Microvascular reconstruction of the lower extremity in the elderly. Clin Plast Surg 1991; 18:459-65.

17. Lorenzetti F, Giordano S, Tukiainen E. Intraoperative hemodynamic evaluation of the latissimus dorsi muscle flap: a prospective study. $J$ Reconstr Microsurg 2012;28:273-8

18. Ludolph I, Lehnhardt M, Arkudas A, Kneser U, Pierer G, Harder Y, Horch RE. Plastic reconstructive microsurgery in the elderly patient. Consensus statement of the German Speaking Working Group for Microsurgery of the Peripheral Nerves and Vessels. Handchir Mikrochir Plast Chir 2017;49:1-8. (in German)

19. Polykandriotis E, Schmidt VJ, Kneser U, Jianming S, Boccaccini AR, Horch RE. Bioreactors in regenerative medicine--from a technical 
device to a reconstructive alternative? Handchir Mikrochir Plast Chir 2012;44:198-203.

20. Weigand A, Beier JP, Arkudas A, Al-Abboodi M, Polykandriotis E, Horch RE, Boos AM. The arteriovenous (av) loop in a small animal model to study angiogenesis and vascularized tissue engineering. $J$ Vis Exp 2016;(117):54676.

21. Weigand A, Beier JP, Hess A, Gerber T, Arkudas A, Horch RE, Boos AM. Acceleration of vascularized bone tissue-engineered constructs in a large animal model combining intrinsic and extrinsic vascularization. Tissue Eng Part A 2015;21:1680-94.

22. Arkudas A, Beier JP, Heidner K, Tjiawi J, Polykandriotis E, Srour S, Sturzl M, Horch RE, Kneser U. Axial prevascularization of porous matrices using an arteriovenous loop promotes survival and differentiation of transplanted autologous osteoblasts. Tissue Eng 2007; 13:1549-60.

23. Arkudas A, Tjiawi J, Saumweber A, Beier JP, Polykandriotis E, Bleiziffer O, Horch RE, Kneser U. Evaluation of blood vessel ingrowth in fibrin gel subject to type and concentration of growth factors. J Cell Mol Med 2009;13:2864-74.

24. Bertram U, Steiner D, Poppitz B, Dippold D, Köhn K, Beier JP, Detsch R, Boccaccini AR, Schubert DW, Horch RE, Arkudas A. Vascular tissue engineering: effects of integrating collagen into a PCL based nanofiber material. Biomed Res Int 2017;2017:9616939.

25. Dippold D, Cai A, Hardt M, Boccaccini AR, Horch R, Beier JP, Schubert DW. Novel approach towards aligned PCL-Collagen nanofibrous constructs from a benign solvent system. Mater Sci Eng C Mater Biol Appl 2017;72:278-83.

26. Rottensteiner U, Sarker B, Heusinger D, Dafinova D, Rath SN, Beier
JP, Kneser U, Horch RE, Detsch R, Boccaccini AR, Arkudas A. In vitro and in vivo biocompatibility of alginate dialdehyde/gelatin hydrogels with and without nanoscaled bioactive glass for bone tissue engineering applications. Materials (Basel) 2014;7:1957-74.

27. Witt R, Weigand A, Boos AM, Cai A, Dippold D, Boccaccini AR, Schubert DW, Hardt M, Lange C, Arkudas A, Horch RE, Beier JP. Mesenchymal stem cells and myoblast differentiation under HGF and IGF-1 stimulation for 3D skeletal muscle tissue engineering. $B M C$ Cell Biol 2017;18:15.

28. Horch RE, Beier JP, Kneser U, Arkudas A. Successful human longterm application of in situ bone tissue engineering. $J$ Cell $\mathrm{Mol}$ Med 2014; $18: 1478-85$.

29. Groll J, Boland T, Blunk T, Burdick JA, Cho DW, Dalton PD Derby B, Forgacs G, Li Q, Mironov VA, Moroni L, Nakamura M, Shu W, Takeuchi S, Vozzi G, Woodfield TB, Xu T, Yoo JJ, Malda J. Biofabrication: reappraising the definition of an evolving field. Biofabrication 2016;8:013001.

30. Wu C, Wang B, Zhang C, Wysk RA, Chen YW. Bioprinting: an assessment based on manufacturing readiness levels. Crit Rev Biotechnol 2017;37:333-54

31. Ravnic DJ, Leberfinger AN, Ozbolat IT. Bioprinting and cellular therapies for type 1 diabetes. Trends Biotechnol 2017; doi: 10.1016/j. tibtech.2017.07.006.

32. Horch RE. Future perspectives in tissue engineering. J Cell Mol Med 2006;10:4-6.

33. Horch RE, Weigand A, Beier JP, Arkudas A, Boos AM. The potential role of telocytes for tissue engineering and regenerative medicine. $A d v$ Exp Med Biol 2016;913:139-47. 